\title{
EVALUATION OF THE DOWNY MILDEW (Plasmopara viticola) AND OF THE GRAY ROT (Botrytis cinerea) ATTACK CORRELATED WITH THE LEAF TREATMENTS AND THE SOIL FERTILIZATION
}

\author{
Marian Lixandru, Sergiu Fendrihan \\ Correspondence address: \\ Research-Development Institute for Plant Protection, \\ 8 Ion Ionescu de la Brad, 013813, Bucharest, Romania, \\ phone: 004-021-2693231; \\ e-mail: lixandrumarian@yahoo.com
}

http://www.doi.org/10.54574/RJPP.14.11

\begin{abstract}
The purpose of the study was to establish the degree of attack of grapevine downy mildew and gray rot on the Muscat Ottonel variety in different technological variants organized in the southern part of Muntenia region in a farm from Hotarele, Giurgiu County in the climatic and meteorological conditions of 2021. The results showed that in the experimental plots treated with 0.5 and $0.6 \%$ foliar fertilizers and $200 \mathrm{~kg}$ phosphorus and potassium active substance per ha, the degree of attack of the two diseases decreases $(0.01 \%$ for Plasmopara viticola and $0.04 \%$ for Botrytis cinerea $)$ comparatively to the untreated control ( $0.13 \%$ and $0.54 \%$ respectively).
\end{abstract}

Key words: downy mildew, grey rot, foliar fertilization, soil fertilization, degree of attack.

\section{INTRODUCTION}

The grapevine downy mildew caused by the Plasmopara viticola pathogen and the gray rot caused by the Botrytis cinerea pathogen are the most harmful diseases of the grapevine producing very significant damage with consequence on production in terms of quantity and quality.

For downy mildew disease, a formula that establishes the climatic conditions with role in dynamics of the pathogen $P$. viticola oospore germination was developed by Gompertz (Rossi et al., 2008) which takes into account the sum of daily temperatures, hourly temperatures (above $10^{\circ} \mathrm{C}$ ), the sum of these daily rates in hours of rain and vapor pressure $(4-5 \mathrm{hPa})$. Basically, the following conditions must be met for the infection to occur - the air temperature higher than $10^{\circ} \mathrm{C}$, a minimum of $10 \mathrm{~mm}$ of precipitation in $24-48 \mathrm{~h}$ and the vine strings must be in the development phase of $10 \mathrm{~cm}$ long (Baldacci, 1947 quoted by Caffi et al, 2009). Regarding the degree of attack of this disease on different varieties of grapevines, researches carried out in Romania (Dumitriu \& Mitrea, 2021) showed that in 2019 this was $1.36 \%$ for Merlot, $1.64 \%$ for Cabernet Sauvignon, $4.30 \%$ for Chardonnay, 3.23\% for Sauvignon Blanc and 5.63\% for Tămâioasă Românească. Suciu et al. (2012) found a degree of attack of $1.88 \%$ for Grasă de Cotnari, $0.74 \%$ for Fetească albă and only $0.99 \%$ for Aligote varieties. It has been found that the attack of disease reduces the effectiveness of water use and photosynthesis at the leaf level (Grimmer et al., 2012) with many negative consequences, including a decrease in production.

Gray rot disease attacks more than 200 species of plants including grapevine (Williamson et al. 2007). To reduce the degree of attack of disease when climatic conditions favor its development, it is necessary to apply some technological measures. Primary infection occurs under favorable conditions of humidity, temperature $\left(2.5 \mathrm{~mm}\right.$ rainfall, about $11^{\circ} \mathrm{C}$ temperature) and plant susceptibility (Kennelly et al., 2007). In Romania, the assessments in the Târnave Vineyard (Tomoioagă \& Mihai, 2005) indicated a degree of attack of $B$. cinerea between 0.5 and $1.5 \%$. A model of $B$. cinerea infection development has been developed by Gonzalez-Dominguez et al. (2015). The authors assess the severity of the infection based on prediction methods that take into account the source of the infection and the period in which it 
occurs. They can predict the severity of infection on inflorescences and young clusters caused by conidia as well as those caused by mycelium. Bove et al. (2018) showed that organo-mineral foliar fertilization leads to increased resistance to these diseases. This method is based on integrated control principle and is accepted for many crops by applying both macro-nutrients (N, P, K, Ca) and micronutrients such as B, Mn, Fe, Zn. (Christensen, 2000).

The purpose of this work was to evaluate the attack degree of downy mildew and gray rot on grapevine (Muscat Ottonel variety) related on the leaf treatments and the soil fertilization.

\section{MATERIALS AND METHODS}

Three experimental blocks were set up, each with 4 variants in 4 repetitions and a control were organized in a vineyard with the Muscat Ottonel variety located in Hotarele commune (Giurgiu County). In the first block, chemical fertilizers based on phosphorus and potassium were applied in doses of 100, 125, 150 and $200 \mathrm{Kg}$. Treatments were also applied with foliar fertilizers in a concentration of $0.4 \%$ in the main four phases of vegetation, respectively before flowering, after flowering, at bunch closure and at ripening. In the second block, all 4 doses of chemical fertilizers with phosphorus and potassium were used and treatment with foliar fertilizers in a concentration of $0.5 \%$ was performed in the 4 previously mentioned phases of vegetation. In the third block, there were applied the same doses of chemical fertilizers with phosphorus and potassium and treatment with foliar fertilizers in a concentration of $0.6 \%$, before flowering, after flowering, at bunch closure and at ripening. In order to establish the degree of attack of downy mildew, 50 leaves were analyzed for each variant, and 50 grapes for each variant were assessed for gray rot attack evaluation.

In 2021 in the area where the experimental fields are located (Table 1), the average air temperature was between $9.7^{\circ} \mathrm{C}$ and $24.4^{\circ} \mathrm{C}$ in period from April to September. The hottest were July and August months. The relative humidity was between $66 \%$ and $81 \%$. The climatic values were provided by the Oltenita Meteo Station located in the area of experiment.

Table 1. Average monthly data of temperature $\left(\mathrm{C}^{\circ}\right)$ and RU\% in 2021 at the Oltenita Meteo Station

\begin{tabular}{|l|c|c|}
\hline \multicolumn{1}{|c|}{ Month } & Average temperature $\left(\mathrm{C}^{\circ}\right)$ & Relative Humidity (\%) \\
\hline January & 2.4 & 86 \\
\hline February & 3.2 & 83 \\
\hline March & 4.9 & 78 \\
\hline April & 9.8 & 69 \\
\hline May & 17.5 & 66 \\
\hline June & 20.5 & 79 \\
\hline July & 24.4 & 68 \\
\hline August & 23.8 & 64 \\
\hline September & 17.2 & 64 \\
\hline October & 9.7 & 81 \\
\hline November & 7.3 & 86 \\
\hline December & 2.9 & 88 \\
\hline
\end{tabular}

\section{RESULTS AND DISCUSSIONS}

Results obtained in this study are presented in figures 1 and 2. Regarding Plasmopara viticola (Fig. 1) it was found that in variants V4 and V8 the degree of attack was $0.01 \%$ and in V12 was $0.04 \%$ comparatively with the control groups (M1-3) where an average of the degree of attack was $0.10 \%$. It can be seen that these are the plots treated with $0.5 \%$ and $0.6 \%$ foliar fertilizers and fertilized with chemical fertilizers, phosphorus and potassium in doses of $200 \mathrm{Kg}$ s.a/ha. Regarding Bortytis cinerea (fig. 2), the degree of attack was $0.16 \%$ in the variant V8 and 
$0.04 \%$ in the variant V12, these being fertilized with $200 \mathrm{~kg} \mathrm{~s}$.a/ha and treatments with foliar fertilizers in concentration of 0.5 and $0.6 \%$. In the untreated control treatments (M1-3), the degree of attack was with an average of $0.54 \%$.

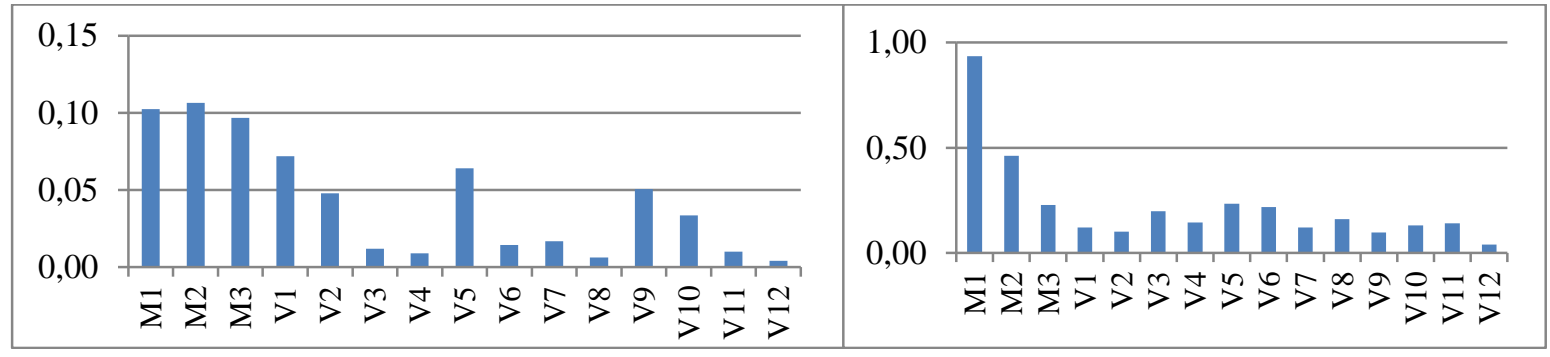

Figure 1. Degree of attack of downy mildew on Muscat Ottonel variety at Hotarele in 2021

Figure 2. Degree of attack of gray rot attack on Muscat Ottonel variety at Hotarele in 2021

The mean weight of bunches and 100 berry fresh mass were positive corelated with the vineyard fertilization quantity/hectare (Table 1). The grape sugar content was between 186.25 $\mathrm{g} / \mathrm{l}$ in untreated check and a maximum of $213.7 \mathrm{~g} / \mathrm{l}$ in case of treatment 12 , receiving a soil fertilization of $200 \mathrm{~kg} / \mathrm{ha}$ phosphorous and potassium and $0.6 \%$ foliar fertilizer during vegetation.

Table 1. Production quality expressed in bunch weight, 100 berry fresh mass and sugar content

\begin{tabular}{|c|c|c|c|c|}
\hline Variant & Treatment description & $\begin{array}{c}\text { Mean } \\
\text { weight of } \\
\text { bunches }(\mathrm{g})\end{array}$ & $\begin{array}{l}100 \text { berry fresh } \\
\text { mass }(\mathrm{g})\end{array}$ & $\begin{array}{c}\text { Sugar } \\
\text { content }(g / L)\end{array}$ \\
\hline M1 & Untreated check $1^{\text {st }}$ series & 160.2 & 192.7 & 202.2 \\
\hline M2 & Untreated check $2^{\text {nd }}$ series & 140.8 & 217.7 & 203.3 \\
\hline M3 & Untreated check $3^{\text {rd }}$ series & 150.2 & 156.2 & 186.25 \\
\hline V1 & $\begin{array}{c}100 \mathrm{~kg} / \mathrm{ha} \text { phosphorous and } \\
\text { potassium }+0.4 \% \text { foliar fertilizer }\end{array}$ & 188.4 & 216.9 & 203.3 \\
\hline $\mathrm{V} 2$ & $\begin{array}{l}125 \mathrm{~kg} / \mathrm{ha} \text { phosphorous and } \\
\text { potassium }+0.4 \% \text { foliar fertilizer }\end{array}$ & 171.4 & 214.9 & 203.3 \\
\hline V3 & $\begin{array}{c}150 \mathrm{~kg} / \mathrm{ha} \text { phosphorous and } \\
\text { potassium }+0.4 \% \text { foliar fertilizer }\end{array}$ & 161 & 200.8 & 205.7 \\
\hline $\mathrm{V} 4$ & $\begin{array}{l}200 \mathrm{~kg} / \mathrm{ha} \text { phosphorous and } \\
\text { potassium }+0.4 \% \text { foliar fertilizer }\end{array}$ & 201.6 & 229.3 & 206.8 \\
\hline V5 & $\begin{array}{l}100 \mathrm{~kg} / \mathrm{ha} \text { phosphorous and } \\
\text { potassium }+0.5 \% \text { foliar fertilizer }\end{array}$ & 172 & 239.4 & 194.2 \\
\hline V6 & $\begin{array}{l}125 \mathrm{~kg} / \mathrm{ha} \text { phosphorous and } \\
\text { potassium }+0.5 \% \text { foliar fertilizer }\end{array}$ & 170 & 232.2 & 195.35 \\
\hline V7 & $\begin{array}{c}150 \mathrm{~kg} / \mathrm{ha} \text { phosphorous and } \\
\text { potassium }+0.5 \% \text { foliar fertilizer }\end{array}$ & 176.2 & 245.7 & 193 \\
\hline V8 & $\begin{array}{l}200 \mathrm{~kg} / \mathrm{ha} \text { phosphorous and } \\
\text { potassium }+0.5 \% \text { foliar fertilizer }\end{array}$ & 185.8 & 239.7 & 209.1 \\
\hline V9 & $\begin{array}{l}100 \mathrm{~kg} / \mathrm{ha} \text { phosphorous and } \\
\text { potassium }+0.6 \% \text { foliar fertilizer }\end{array}$ & 162 & 199.5 & 204.5 \\
\hline V10 & $\begin{array}{l}125 \mathrm{~kg} / \mathrm{ha} \text { phosphorous and } \\
\text { potassium }+0.6 \% \text { foliar fertilizer }\end{array}$ & 179.4 & 274.5 & 204.5 \\
\hline V11 & $\begin{array}{l}150 \mathrm{~kg} / \mathrm{ha} \text { phosphorous and } \\
\text { potassium }+0.6 \% \text { foliar fertilizer }\end{array}$ & 179.6 & 241.6 & 212.5 \\
\hline V12 & $\begin{array}{l}200 \mathrm{~kg} / \mathrm{ha} \text { phosphorous and } \\
\text { potassium }+0.6 \% \text { foliar fertilizer }\end{array}$ & 209 & 269.3 & 213.7 \\
\hline
\end{tabular}




\section{CONCLUSIONS}

The best results were obtained in the vineyard experimental treatments treated with foliar fertilizers in concentration of $0.5 \%$ and $0.6 \%$ and fertilized with $200 \mathrm{~kg}$ of phosphorus and potassium/ha, respectively variants V4, V8, V12, these having the lower degrees of attack of the two pathogenic fungi. The best quality of production was recorded in the V8 and V12 variants fertilized with a combination of $200 \mathrm{Kg}$ (active substance) phosphorus and potassium/ha and foliar fertilizers in a concentration of $0.5 \%$ and $0.6 \%$. It is necessary to further experiment with this technology, in order to confirm the results obtained but also to elaborate recommendations to the farmers.

\section{ACKNOLEDGEMENT}

This work was performed within framework of the project no 4690/2018 supported by national budget. We thank to the company SC Delagro Delmica SRL from Hotarele, Giurgiu for the support in carrying out the experiments.

\section{REFERENCES}

BOVE, F., CAFFI, T., PONI, S., LANGUASCO, L., ROSSI, V. (2018) Evaluation of an organo -mineral fertilizer effectiveness in Plasmopara viticola control. Giornate Fitopatologhice, 2, 357-364.

CAFFI, T., ROSSI, V., BUGIANI, R., SPANNA, F., FLAMINIL, COSSU, A., NIGRO, C. (2009). A model predicting in different primary infections of Plasmopara viticola in different grape growing areas of Italy. Journal of Plant Pathology, 91, 3, 535-548.

DUMITRIU, D.G., MITREA, R. (2021). Results regarding on the dynamics of the attack of the pathogen Plasmopara viticola in the climatic conditions of the years 2019-2020, in the Segarcea wine farm archidiocese Craiova, Judetul Dolj. Current Trends in Natural Sciences, 10, 19, 362-367.

GRIMMER, M. K., FOULKES, P., NEIL, D., PAVELEY N.D. (2012). Foliar pathogenesis and plant water relations: a review. Journal of Experimental Botany, 63, 12, 4321-4331

GONZALEZ-DOMINGUEZ, E., CAFFI, T., CILIBERTI, N., ROSSI, V. (2015). A Mechanistic Model of Botrytis cinerea on Grapevines That Includes Weather, Vine Growth Stage, and the Main Infection Pathways. PLoS ONE 10(10): e0140444. doi:10.1371/journal. pone.0140444

KENNELLY, M.M., GADOURY, D.M., WILCOX, W.F., MAGAREV, P.A., SEEM, R.C. (2007). Primary infection, lesion productivity, and survival of sporangia in the grapevine downy mildew pathogen, Plasmopara viticola. Phytopathology, 97, 512-522.

CHRISTENSEN, P. (2000). Foliar Fertilization of Grapevines University of California Tulare County Cooperative Extension Pub. NG6-94

ROSSI, V., CAFFI, T., BUGIANI, R., SPANNA, F., DELlA VALlE, D. (2008). Estimating the germination dynamics of Plasmopara viticola oospores using hydro-thermal time S. Plant Pathology, 57, 216-226. Doi: 10.1111/j.1365-3059.2007.01738.x

SUCIU, L., PUIA, C., FLORIAN, V., MICLEA, R., BUNEA, C.I. (2012). The Behaviour of Vine Varieties to Downy Mildew Attack (Plasmopara Viticola Berk \& Curt) in Ampelographic Collection in the Conditions of USAMV Cluj - Napoca. ProEnvironment, 5, 221 - 226.

TOMOIOAGA, L., MIHAI, C. (2005). Putregaiul cenusiu, putregaiul acid si putregaiul verde al strugurilor, evolutia atacului si managementul integrat in conditiile Podgoriei Tarnave. Revista Protectia Plantelor, 59-60.

WILLIAMSON, B., TUDZYNSCKI, B., TUDZYNSCKI, P., VAN KAN, J.A.L. (2007). Botrytis cinerea: the cause of grey mould disease. Molecular Plant Pathology, 8, 5, 561-580. 